\title{
Wet avalanches: long-term evolution in the Western Alps under climate and human forcing
}

\author{
Laurent Fouinat $^{1}$, Pierre Sabatier ${ }^{1}$, Fernand David $^{2}$, Xavier Montet ${ }^{3}$, Philippe Schoeneich $^{4}$, Eric Chaumillon ${ }^{5}$, \\ Jérôme Poulenard ${ }^{1}$, and Fabien Arnaud ${ }^{1}$ \\ ${ }^{1}$ EDYTEM, University Savoie Mont Blanc, CNRS, 73376 Le Bourget-du-Lac CEDEX, France \\ ${ }^{2}$ CEREGE, University Aix-Marseille, 13545 Aix-en-Provence, France \\ ${ }^{3}$ University of Geneva Department of Radiology and Medical Informatics Genève, 1211 Geneva, Switzerland \\ ${ }^{4}$ IUGA, University Grenoble Alpes, 38100 Grenoble, France \\ ${ }^{5}$ LIENSs University of La Rochelle, 17000 La Rochelle, France
}

Correspondence: Laurent Fouinat (laurent.fouinat@gmail.com)

Received: 2 March 2018 - Discussion started: 19 March 2018

Accepted: 2 August 2018 - Published: 11 September 2018

\begin{abstract}
Understanding wet avalanche intensity and the role of past environmental changes on wet avalanche occurrence is a main concern especially in the context of a warming climate and accelerated environmental mutations. Avalanches are closely related to fast cryosphere changes and may cause major threats to human society. Here, we used the sedimentary archive of the Alpine Lake Lauvitel (Lac du Lauvitel; western French Alps) to establish the first longterm avalanche record in this Alpine region. For this purpose, we used a novel CT-scan methodology that allows the precise identification of coarse material - from sand to pebble transported to the lake and embedded within the finer continuous sedimentation. We identified a total of 166 deposits over the last $3300 \mathrm{yr}$ cal. BP. In parallel, a detailed pollen analysis gave an independent record of environmental changes. Based on modern observation, lake monitoring, seismic investigations and sedimentological evidences, coarse material deposits were attributed to wet avalanche events. Our results highlight the effect of vegetation cover on the avalanche hazard while a period of strong frequency increase occurred after $780 \mathrm{yr}$ cal. BP. In Lake Lauvitel, this period corresponds to a major forest clearance induced by the rise of human land use. Climate forcing on the avalanche hazard was investigated before and after the vegetation shift. On a multicentennial scale, wet avalanches preferably occur during periods of larger glacier extent, in which higher winter precipitation probably generates a sufficiently thick snow cover. On a sub-centennial scale, avalanches are more frequent dur-
\end{abstract}

ing periods of relative warming, resulting in a destabilization of the same snow cover in spring season. Our results highlight as well the role of forest cover in mitigating wet snow avalanches' occurrence. In the context of predicted warmer temperatures, this study raises the question of whether a wet avalanche hazard increase may be expected in the near future especially at higher altitudes.

\section{Introduction}

Avalanche hazard is one of the major threats to human societies in mountain environments, and in the context of warmer temperatures, avalanche occurrence patterns will likely be modified by a reduction of dry snowpack and an increase in wet snowpack (Castebrunet et al., 2014). Complex meteorological conditions over a period of days to several weeks control the snowpack stabilization, and occurrence of wet avalanches highly depends on temperature conditions because they are more likely to occur when the average daily temperature exceeds $0{ }^{\circ} \mathrm{C}$ (Baggi and Schweizer, 2009). Furthermore, regional models are predicting an increase in wet avalanche activity for the coming decades, mostly related to an earlier occurrence in the spring season and an avalanche risk expected at higher altitude (Lazar and Williams, 2008; Castebrunet et al., 2014). In this study, we focus on wet avalanches, considered as dense flows characterized by wet snow in which liquid water content is around 3 vol\%- 
15 vol \% (Fierz et al., 2009). Those glide on the substratum and are able to transport coarse detrital sediments such as gravels and pebbles (Luckman, 1977; Moore et al., 2013). Within the last 40 years, snow cover duration has decreased, and the number of wet snow avalanches in the springtime is increasing (Valt and Paola, 2013; Ancey and Bain, 2015). For risk management, it is crucial to understand processes favoring the occurrence of such events over long periods. In this context, it could be valuable to develop a natural archive in which those events and their potential triggering factors are recorded. In that aim, most studies have used dendrochronology and tree-ring growth disturbances to date and identify avalanche events (Corona et al., 2010; Martin and Germain, 2016). This methodology (i) allows annual resolution dating, (ii) estimates avalanche extension and (iii) provides natural chronicles of up to several centuries. However, longscale records of avalanche hazards remain scarce. Multiple millennial-scale avalanche records on a regional basis would improve the understanding of avalanche occurrence and allow long-term comparison with existing climate and environmental change records (Stoffel and Bollschweiler, 2008). In addition, natural vegetation cover in the Alps was modified by human practices (Touflan et al., 2010), and potential tree-ring-based avalanche records may have been altered. In this context, lake sediment archives can provide an alternative, with the advantage of providing (i) longer archives and (ii) the coeval record of other environmental parameters such as erosion or vegetation dynamics. However, to record avalanche events in lake sediment, the watershed connected to the lake system must present steep slopes and corridors that can channel sediment to the lake. The detection of avalanche deposits in lake sediment is based on the identification of poorly sorted sediment with coarse grains in a fine matrix (Nesje et al., 2007; Vasskog et al., 2011), as opposed to debris flow deposits, characterized by fining upward trend with a coarse grain base (Iverson, 1997; Sletten et al., 2003). Classically, those coarse grains were identified using a wet sieving technique, which is still a time-consuming and destructive method. Lake Lauvitel (Lac du Lauvitel) is located in the western French Alps and has preserved gravels originating from wet avalanches within its sediment. We based our avalanche chronicle on a novel CT-scan methodology to precisely reference and quantify the coarse grains in the lake sediment (Fouinat et al., 2017a). This avalanche chronicle includes the flood deposit occurrence and palynological analysis over the last $3300 \mathrm{yr}$ cal. BP, allowing us to discuss the respective impact of past human and climate forcing on longterm wet avalanche occurrence patterns.

\section{Material and methods}

\subsection{Study area}

Lake Lauvitel $\left(44.96667^{\circ} \mathrm{N}, 6.05000^{\circ} \mathrm{E}\right), 1500 \mathrm{~m}$ a.s.l. (meters above sea level) is located in the western French Alps,
$35 \mathrm{~km}$ southeast of Grenoble (Fig. 1). The total drainage area is approximately $15.1 \mathrm{~km}^{2}$, and the lake surface covers $0.35 \mathrm{~km}^{2}$. This lake was formed by a natural dam created by a large rockslide dated by Beryllium exposure age back to $4.7 \pm 0.4 \mathrm{kyr}{ }^{10} \mathrm{Be}$ (Delunel et al., 2010). The porous outlet through the dam induces a seasonal water table height variation of approximately $20 \mathrm{~m}$, with a maximum height reached in July $(61 \mathrm{~m})$ and a minimum in May $(40 \mathrm{~m})$. From late December to early May, the lake surface is frozen, and snow covers most of the drainage area. The maximum watershed elevation is $3169 \mathrm{~m}$ a.s.l., and the bedrock is mainly composed of granite and gneiss with minor outcrops of Triassic limestone. The Petit Embernard torrent drains a regularly sloped $\left(10^{\circ}\right)$ subcatchment, and a large delta has formed at the lake entrance. Two smaller streams (Plan Vianney and Héritère) are present on the western side of the lake and are characterized by steep slopes of approximately $40^{\circ}$. Three gullies (C1, C2 and C3) are also present, and snow accumulation resulting from avalanche deposition is sometimes observed during the spring season at the bottom of the gullies (Fouinat et al., 2017a). Current vegetation cover in the watershed is composed of a spruce forest present around only the deltaic form south of the lake. The western part of the watershed exhibits vegetation composed of shrubs (Juniperus and Alnus) especially in the vicinity of the avalanche corridors of the $\mathrm{C} 2$ and $\mathrm{C} 3$ gullies. Based on direct observations in the western part of the watershed, shrubs can also be associated with isolated trees, mostly Abies and Pinus Cembra. The higher-altitude vegetation can be described as an Alpine lawn, especially in the southern part of the watershed. The lake is situated in the restricted area of Écrins National Park, and since 1995, the southern part of the watershed has been one of the only integrally protected areas in France, where human presence is strictly prohibited, allowing for the regrowth of natural vegetation.

\subsection{Lake coring}

A $15.46 \mathrm{~m}$ long sediment core was extracted in July 2011 using a Uwitec piston coring device installed on a coring platform. The core was retrieved from the deepest part of the lake at $61 \mathrm{~m}$ depth $\left(44.96898333^{\circ} \mathrm{N}, 6.06258333^{\circ} \mathrm{E}\right)$. The sediment sequence LAU11 (IGSN: IEFRA007I; codes refer to an open international database, www.geosamples.org, last access: 11 August 2018) was composed of five overlapping coring holes, LAU11-01, LAU11-02, LAU11-03, LAU11-04 and LAU11-07, respectively, made of 9, 2, 1, 1 and 5 sections. The high number of coring holes is due to the presence of gravel and stones layers, sometimes impenetrable, but insures a $1 \mathrm{~m}$ sediment overlap providing a continuous record. A short gravity core (LAU11P2) was also taken to provide a well-preserved water-sediment interface that was subsequently correlated to the composite sequence. Sediment cores were split into two halves at the EDYTEM laboratory. Each section was described in detail and pictures were taken 

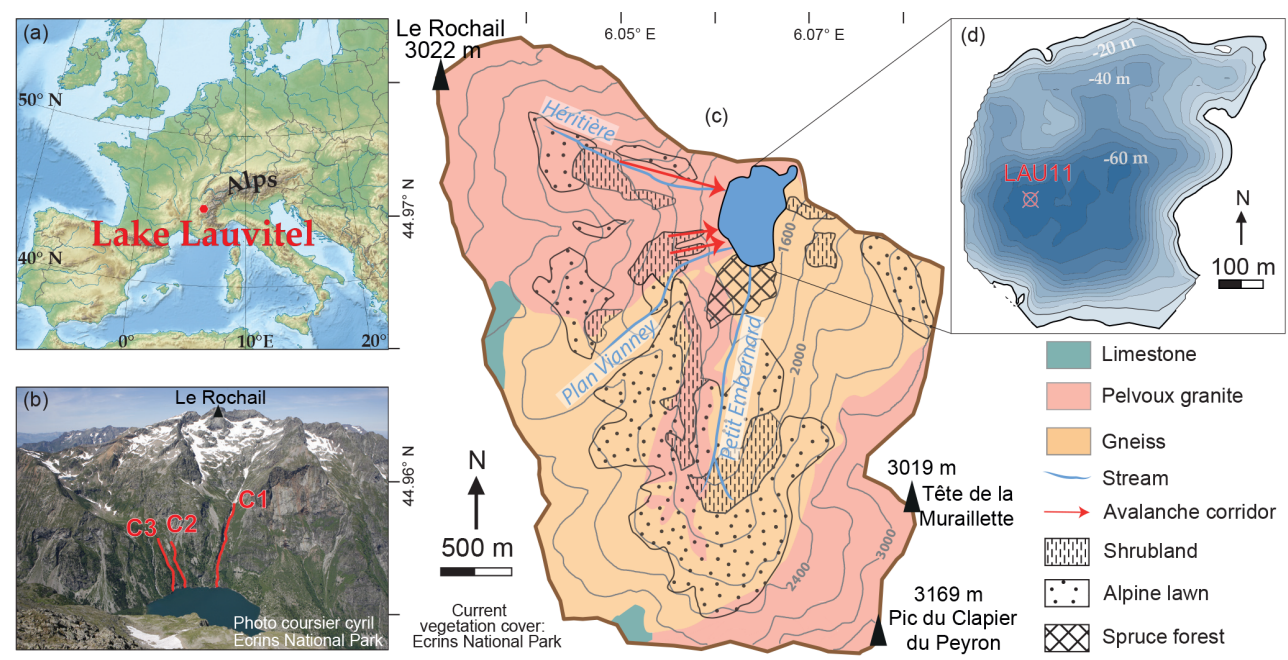

Figure 1. (a) Location of Lake Lauvitel in the western Alps. (b) Photograph towards the west of the lake watershed exhibiting three avalanche corridors. (c) Simplified geological maps of Lake Lauvitel watershed and current vegetation cover. (d) Lake bathymetry and position of LAU11 sediment core.

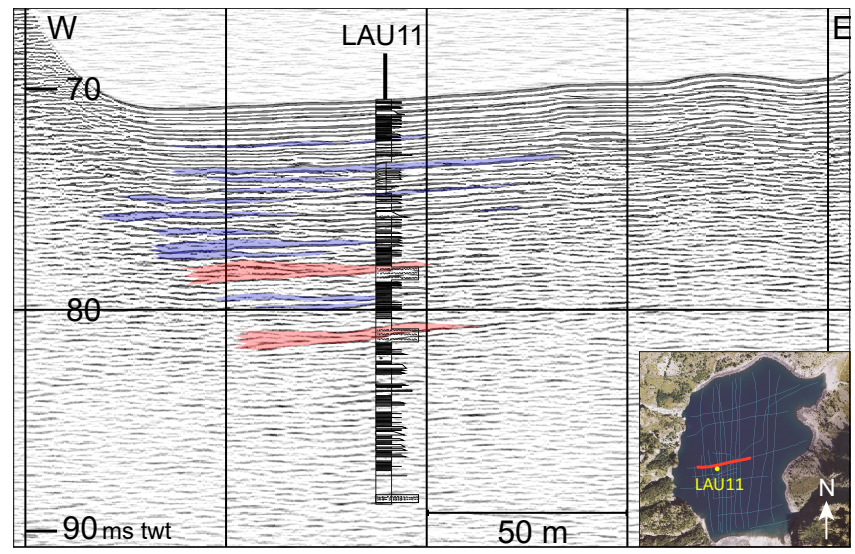

Figure 2. Interpreted seismic profile $03 \_6$ on a W-E direction. LAU11 coring point is indicated by the vertical bar and the simplified core results. Red units are interpreted as mass-wasting deposits and thinner blue layers are interpreted as containing coarse sediments.

at a 20 pixel $\mathrm{mm}^{-1}$ resolution. Lithological description of the sequence allowed the identification of different sedimentary facies. The composite sediment sequence named LAU11 was built using distinct marker layers from the overlapping section of parallel holes.

\subsection{High-resolution seismic survey}

In September 2012, we acquired about $15 \mathrm{~km}$ of highresolution seismic profiles in Lake Lauvitel (28 profiles; Fig. 3). Positioning of seismic profiles was obtained using a GPS system with its antenna directly mounted on the seismic profiler. The seismic profiler was the IKB-Seistec, a boomer plate associated with a line-in-cone short streamer (Simpkin and Davis, 1993). This seismic profiler dedicated to shallow waters allowed us to obtain profiles in the lake system. The band-pass frequency was 1 to $10 \mathrm{kHz}$, giving a vertical resolution of about $20 \mathrm{~cm}$. A $50 \mathrm{~J}$ power supply was selected. The shot interval was $250 \mathrm{~ms}$, corresponding to distance between adjacent traces of about $25 \mathrm{~cm}$ for a ship speed of about 2 knots.

\subsection{Sedimentary analysis}

The grain size distribution on most of the identified layers was measured with a $5 \mathrm{~mm}$ sampling step using a Malvern Mastersizer 800 laser particle sizer. Ultrasonics were used to dissociate particles and to avoid flocculation. We then used the median (Q50) and the coarsest (Q90) fractions, in addition to the sorting parameter to characterize interbedded deposits (Mulder et al., 2001; Passega, 1964; Vasskog et al., 2011; Wilhelm et al., 2015b).

\subsection{CT-scan imagery}

Several layers of gravel-sized mineralogic particles were identified in the LAU11 sediment sequence. To characterize the coarse fraction, a CT-scan analysis was performed on split sediment cores at the Hôpitaux Universitaires de Genève (HUG) following the methodology from Fouinat et al. (2017a). The entire composite sediment sequence was divided into 15445 frames of $1 \mathrm{~mm}$ thickness. Image resolution parameter was set to $512 \times 512$ pixels, with a pixel corresponding to $500 \times 500 \mu \mathrm{m}$. Images were then stacked using the ImageJ Fiji application (Schindelin et al., 2012) to obtain $0.25 \mathrm{~mm}^{3}$ resolution voxels (i.e., volumetric pixels) for the sediment sequence. Image treatments were performed using 

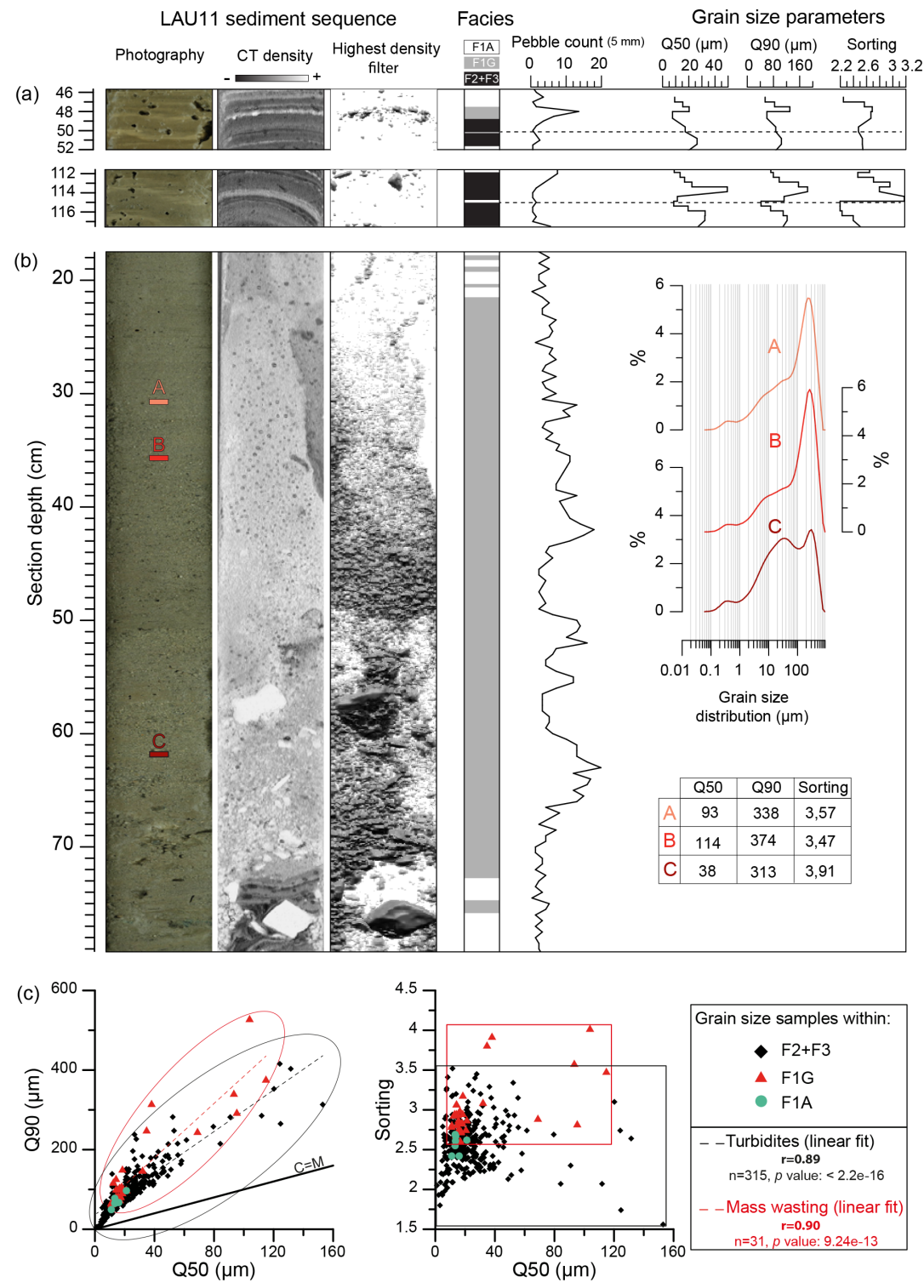

Figure 3. LAU11 core photography compared with CT-scan radiograph and high-density filter in function of depth. Images are plotted versus grain size parameters and the pebble counts as a sum in a $5 \mathrm{~mm}$ depth. (a) Typical facies found in Lauvitel sediment sequence. (b) Outstanding F1G $52 \mathrm{~cm}$ thick layer identified at $6.86 \mathrm{~m}$ in the sequence. (c) Biplots exhibiting median (Q50) versus coarser percentile (Q90) and sorting parameter of LAU11 grain size measurements in function of deposits types.

the 3-D object counter plugin (Bolte and Cordelieres, 2006). First, we isolated the highest-density values recovered in the sediment cores in order to identify the densest sedimentary elements corresponding to the outlier presence of gravel-size mineralogic element within the finer sediment matrix. The 3D object counter was used to reconstruct the precise depth in a 3-D coordinate system (Fouinat et al., 2017a).

\subsection{Palynological analysis}

In total, 32 samples of $1 \mathrm{~cm}^{3}$ of sediment were taken along the sequence between 0.09 and $15.41 \mathrm{~m}$ at variable intervals within the event-free sedimentation for better grain preservation and more accurate statistical representation. The samples were prepared for pollen analysis following the standard acetylation and hydrofluoric acid method (Faegri et al., 1989). The pollen sum was at least 500 grains. The software package GpalWin (Goeury, 1988) was used to construct pollen diagrams.

\subsection{Chronology}

The chronology of the Lake Lauvitel sediment sequence is based on short-lived radionuclides ${ }^{226} \mathrm{Ra},{ }^{210} \mathrm{~Pb},{ }^{241} \mathrm{Am}$ and 
${ }^{137} \mathrm{Cs}$ (Fouinat et al., 2017a), with non-regular sampling following facies distinction avoiding thick beds. In complement, we selected 19 samples on terrestrial plant macroremains for ${ }^{14} \mathrm{C}$ measurements. Those were performed by an accelerator mass spectrometer (AMS) at the Poznań Radiocarbon Laboratory and at the Laboratoire de Mesure ${ }^{14} \mathrm{C}$ (LMC14) ARTEMIS at the French Alternative Energies and Atomic Energy Commission (CEA) Institute at Saclay (Table 1). The ${ }^{14} \mathrm{C}$ ages were converted to "calendar" years using the calibration curve IntCal13 (Reimer et al., 2013). The age-depth model was then generated using $\mathrm{R}$ software and the R-code package "Clam" version 2.2 (Blaauw, 2010).

\section{Results}

\subsection{Seismic survey}

The Lauvitel lake basin consists of a shallow northern area and a deep southern area. The northern area displays sediment accumulation of less than $2 \mathrm{~ms}$ twt lying on an acoustic basement, whereas the southern basin exhibits a succession of subhorizontal medium- to strong-amplitude reflectors increasingly discontinuous with depth (Fig. 2). The deepest strong-amplitude reflector is lying at approximately $18.8 \mathrm{~ms}$ twt. However, clear identification of substratum upper surface was not possible probably related to signal attenuation. The 03_6 profile shot along a W-E direction shows two units (Fig. 2 in red) pinching out toward the east, displaying a chaotic internal configuration and multiple reflectors downlapping on two strong-amplitude subhorizontal reflectors lying at 11.8 and $17.3 \mathrm{~ms}$ twt. Thinner units pinching out basinward (Fig. 2 in blue) are based on subhorizontal and strong-amplitude reflectors and topped by an undulated surface displaying convex-up reflectors.

\subsection{Sedimentology}

\subsubsection{Core description and lithology}

Based on macroscopic observations, grain size analysis and CT-scan imagery we identified four different facies in the LAU11 sediment sequence. F1 is composed of homogeneous to finely laminated silty mud. Two subclasses can be distinguished according to grain size parameters; F1A is characterized by a homogeneous median value (Q50) around $13.5 \mu \mathrm{m}$ and low sorting values (<2.7) (Fig. 3a).

On the contrary, F1G was characterized by the presence coarse grains and higher sorting values (> 2.6). In F1G, CT high-density filter analysis reveals the presence of multiple pebbles disposed in layers parallel to surrounding lamination, expressed as a count of gravels in a $5 \mathrm{~mm}$ sediment thickness (Fig. 3a). In this figure, an example of F1G layer is shown where 14 individual pebbles were identified. Whereas most of the 166 F1G layers had thicknesses comprised between 0.2 and $5.4 \mathrm{~cm}$, we found three outstanding layers of $48.5,52$ and $54 \mathrm{~cm}$, respectively, at $6.35,8.49$ and $14.58 \mathrm{~m}$ of depth. The $52 \mathrm{~cm}$ layer (Fig. 3b) exhibits a multimodal grain size distribution characterized by median values of 38 to $114 \mu \mathrm{m}$, coarser percentile of 313 to $374 \mu \mathrm{m}$ and bad sorting values (>3.4), with no indication of a fining upward trend. Macroscopic observations revealed the presence of multiple coarse grains in this layer, supported by CT high-density filter identification of numerous dense objects (gravels and pebbles). The corresponding graph of pebble counts has identified a total of 355 individuals, but based on the CT images the number of individuals is more likely to be higher. The difference could be due to the proximity of individual pebbles making it difficult to identify them separately by image analysis. The multimodal grain size distribution indicates the input of a coarse sandy fraction accompanied by pebbles within a fine sediment matrix in accordance with a previous study on the upper sediment sequence of Lake Lauvitel (Fouinat et al., 2017a). Additionally, we found no evidence of erosive base on these F1G layers, and no gradation indicating transport by water current; thus, F1G layers are interpreted as masswasting deposits (Fouinat et al., 2018).

F1 is interbedded with a total number of 153 normally graded beds, characterized by a coarse sandy layer at the bottom to a progressively thinning upward silt size sequence. These layers are identified as facies F2. They are almost always associated with a thin white clay-rich layer identified as facies F3. Sometimes, the presence of pebbles was identified in the upper part of F2 and may either be related to the lamina deformation during coring, penetration of individual pebbles while deposited on unconsolidated sediment at the bottom of the lake or transported by a turbidity flow (Fig. 3). Due to their detrital-rich content and the fining upward trend (F2 plus F3) sequences represent high-energy deposits interpreted as turbidites. The origin of each deposit is discussed in Sect. 4.1.

Plotting the median grain size versus the coarsest and sorting parameter (Fig. 3c) highlights two distinct patterns. The normally graded beds ( $\mathrm{F} 2$ plus $\mathrm{F} 3$ ) have a positive correlation of $r=0.89\left(n=315, p\right.$ value: $\left.<2.2 \times 10^{-16}\right)$, and the masswasting deposit layers have a correlation of $r=0.90(n=31$, $p$ value: $9.24 \times 10^{-13}$ ) and higher Q90 values for an equivalent Q50. The differentiation between the two facies is particularly clear for high median value samples showing, respectively, higher Q90 and sorting values for the mass-wasting deposits compared to turbidites. In contrast, F1A shows almost no grain size changes and thus has a low-energy depositional environment.

\subsubsection{Correlation between seismic and sedimentary results}

The base of the two units (Fig. 2 in red) and the strongest reflector, found, respectively, at $11.8,17.3$ and $18.8 \mathrm{~ms}$ twt correspond to $5.9,8.6$ and $15.3 \mathrm{~m}$ of sediment depth using an mean acoustic velocity of $1630 \mathrm{~ms}^{-1}$. Basal strong-amplitude reflectors are indicative of strong acoustic 
Table 1. Radiocarbon ages for LAU11 sediment sequence. Bold samples are excluded dates in the age model.

\begin{tabular}{llrlrrr}
\hline Sample name & Lab. code & Depth $(\mathrm{cm})$ & Sample type & ${ }^{14}$ C yr BP & BP range (cal. yr) & Prob. \\
\hline LAU1102A-1 & Poz-57964 & 188 & Twig & $150 \pm 30$ & $0-283$ & 95 \\
LAU1101E1-1 & Poz-55504 & 247 & Twig & $145 \pm 30$ & $3-284$ & 95 \\
LAU1101B-1 & Poz-55502 & 339 & Twig & $85 \pm 30$ & $307-468$ & 95 \\
LAU1101D1-1 & Poz-55503 & 617 & Twig & $915 \pm 30$ & $691-896$ & 95 \\
LAU1101D2-1 & Poz-57963 & 729 & Twig & $1435 \pm 30$ & $764-919$ & 95 \\
LAU1101B-1 & Poz-55501 & 923 & Twig & $1296-1378$ & 95 \\
LAU1101E1-1 & Poz-57955 & 924 & Plant macroremains & $1500 \pm 35$ & $1310-1531$ & 95 \\
LAU1101E1-2 & Poz-57956 & 1000 & Leaf & $1490 \pm 30$ & $1307-1513$ & 95 \\
LAU1101E2-1 & Poz-57958 & 1032 & Plant macroremains & $1725 \pm 30$ & $1305-1704$ & 95 \\
LAU1101E2-2 & Poz-55505 & $\mathbf{1 1 0 8}$ & Twig & $\mathbf{1 8 7 5} \pm \mathbf{3 0}$ & $\mathbf{1 7 2 8}-\mathbf{1 8 7 9}$ & $\mathbf{9 5}$ \\
LAU1101F1-1 & Poz-54236 & 1245 & Plant macroremains & $2080 \pm 30$ & $1953-2138$ & 95 \\
LAU1101F1-2 & Poz-54237 & 1290 & Plant macroremains & $2270 \pm 30$ & $2160-2348$ & 95 \\
LAU1101F1-3 & Poz-57959 & 1335 & Roots & $2150 \pm 30$ & $2010-2304$ & 95 \\
LAU1101F1-4 & Poz-54238 & 1380 & Twig & $2215 \pm 35$ & $2324-2150$ & 95 \\
LAU1101F2-1 & Poz-57960 & 1412 & Tree bark & $2400 \pm 30$ & $2348-2678$ & 95 \\
LAU1101F2-2 & Poz-54239 & $\mathbf{1 4 4 5}$ & Twig & $\mathbf{2 9 9 0} \pm \mathbf{3 0}$ & $\mathbf{3 0 6 9 - 3 3 2 1}$ & $\mathbf{9 5}$ \\
LAU1101F2-3 & Poz-57962 & 1468 & Plant macroremains & $2600 \pm 30$ & $2716-2811$ & 95 \\
LAU1101G-1 & Poz-54240 & 1516 & Leaf & $2925 \pm 30$ & $2975-3163$ & 95 \\
LAU1101G-2 & Poz-59792 & 1546 & Plant macroremains & $3070 \pm 35$ & $3182-3366$ & 95 \\
\hline
\end{tabular}

impedance changes. Considering a change of grain size can be responsible for a change of reflectivity (Billeaud et al., 2005), the marked reflectors can indicate the presence of the coarse sediment layers. Moreover, both the undulated surface, potentially related to irregular thickness in sedimentary layers, as well as chaotic facies and the pinching out in a basinward direction support the sedimentary interpretation of mass-wasting deposits. Given the depth resolution of the seismic profile, these three reflectors can be related to the three outstanding thick layers found in the sediment core at $6.35,8.49$ and $14.58 \mathrm{~m}$.

\subsection{CT-scan-based imagery}

The CT-scan methodology allowed the identification of 6433 individual mineralogical elements of at least 13 voxels $\left(3.25 \mathrm{~mm}^{3}\right)$, corresponding to a minimum diameter of $2 \mathrm{~mm}$. Total pebble repartition in the sediment core is described in terms of pebble counts per $5 \mathrm{~mm}$ interval (Fig. 4). We discarded the 2536 pebbles contained in the flood layers (F2 plus F3). At the end, 3897 pebbles were identified in the sediment facies F1G and interpreted as mass-wasting deposits. The average volume of a particle was found to be $81 \mathrm{~mm}^{3}$, corresponding to an average particle diameter of $4.3 \mathrm{~mm}$. Based on these results, we identified 166 pebble-rich layers cumulating in at least four pebbles identified in $5 \mathrm{~mm}$ intervals. This limit of individuals within a deposit was found to be representative of historical avalanche records in the valley and exclude pebbles entering lake sediment related to slope processes such as natural chemical or mechanical weathering induced by frost and vegetation roots (Fouinat et al., 2017a).

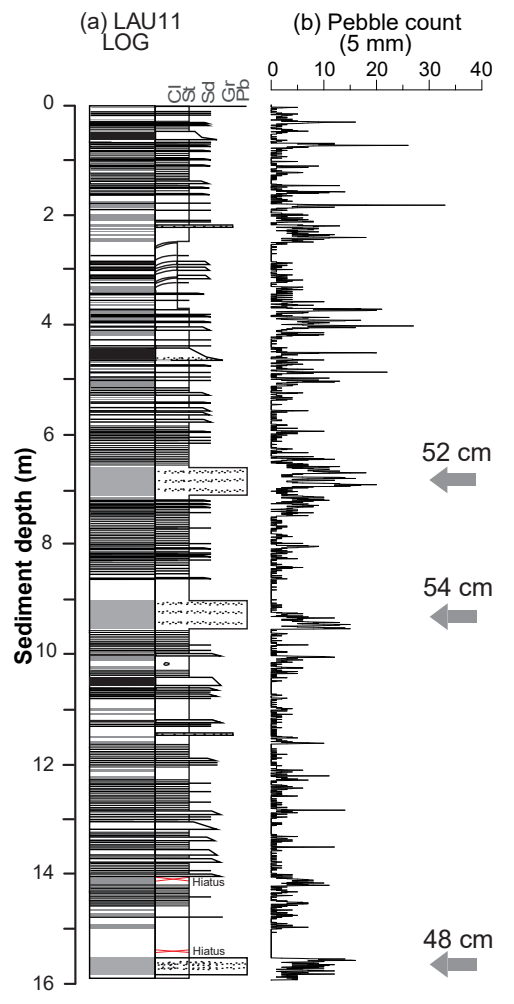

Figure 4. (a) LAU11 sediment sequence log versus (b) the total pebbles counts in function of depth. Each of the three outstanding F1G layer deposits' thickness identified at depths of 6.35, 8.49 and $14.58 \mathrm{~m}$. 


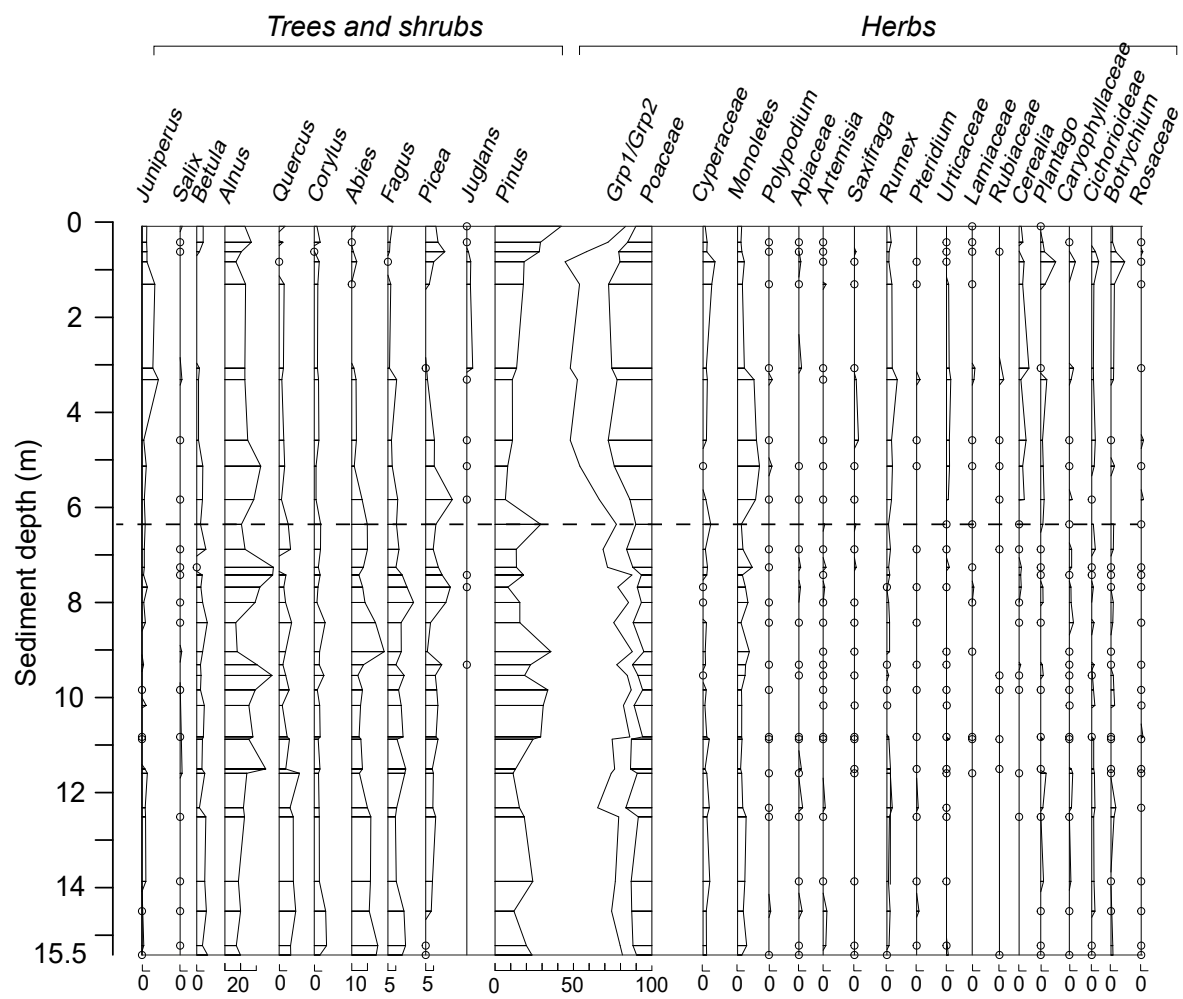

Figure 5. Simplified pollen of LAU11 sediment sequence in function of depth as a percentage of the pollen sum. Dashed line refers to depth of $6.35 \mathrm{~m}$. Dots refer to values below $1 \%$ of the pollen sum.

\subsection{Pollen record}

The pollen diagram of Lake Lauvitel is expressed as percentages calculated from the total sum (Fig. 5). At $6.35 \mathrm{~m}$, we identified a sharp vegetation change. From 15.45 to $6.35 \mathrm{~m}$, the majority of the pollen came from trees and shrubs, accounting for $65 \%$ to $90 \%$ of the pollen sum. The large representation of Pinus, Abies and Picea in the tree pollen can be interpreted as the presence of a spruce forest in the watershed, probably a larger one than is there today. Current vegetation maps show the presence of such a forest but only at the southern part of the lake and associated with several isolated Abies and Pinus cembra trees in the western steep slopes. The palynological results suggest a more expansive forest than currently exists that probably also extended to the western watershed slopes. Alnus is present in $10 \%$ to $25 \%$ of the total pollen count, which is quite an important proportion because they grow close to a source of water or in avalanche corridors. Alnus pollen, in this case, may be overrepresented due to the tributary transport. In addition, below $6.35 \mathrm{~m}$, we found some evidence of Rumex and Plantago, providing evidence for a limited but present grazing pressure, as well as traces of Cerealia. Overall, the pollen record provides evidence of the presence of human practices in the watershed, and these practices may have increased until a major vegetation change that is recorded $6.35 \mathrm{~m}$ depth in the sequence. Indeed, above this depth, the Poaceae proportion rapidly exceeds more than $50 \%$ of the pollen sum, and tree pollen, especially Pinus, Picea and Abies, exhibits a sharp decline. The decline of tree pollen coincides with an increase in the percentages of undetermined monolete spores, and no change in Polypodium and Pteridium, which are also issued from ferns. From $6.35 \mathrm{~m}$ to the top of the sequence, we observe an increase in the anthropic taxa percentages. Rumex and Plantago were already present before and exhibit an increase, mirroring a rise in the grazing pressure, associated with the presence of Cerealia and Juglans, evidence of crops and tree gardening. Based on the pollen record, the maximum anthropic pressure is reached approximately at $4.58 \mathrm{~m}$, when the Juniperus bushes reached a maximum, the Picea disappeared, and there were very low percentages of Abies and Pinus. From $1.3 \mathrm{~m}$ to the top, pollen results show a progressive increase in trees probably expressing the continued decrease in land use in this watershed.

\subsection{Chronology}

The recent sediment deposition study by Fouinat et al. (2017a) was based on short-lived radionuclides of which ${ }^{210} \mathrm{~Pb}$ excess was calculated as the difference between total ${ }^{210} \mathrm{~Pb}$ and ${ }^{226} \mathrm{Ra}$ activities. The low values of ${ }^{210} \mathrm{~Pb}_{\mathrm{ex}}$ were excluded to reconstruct a synthetic sedimentary record fol- 
(a)

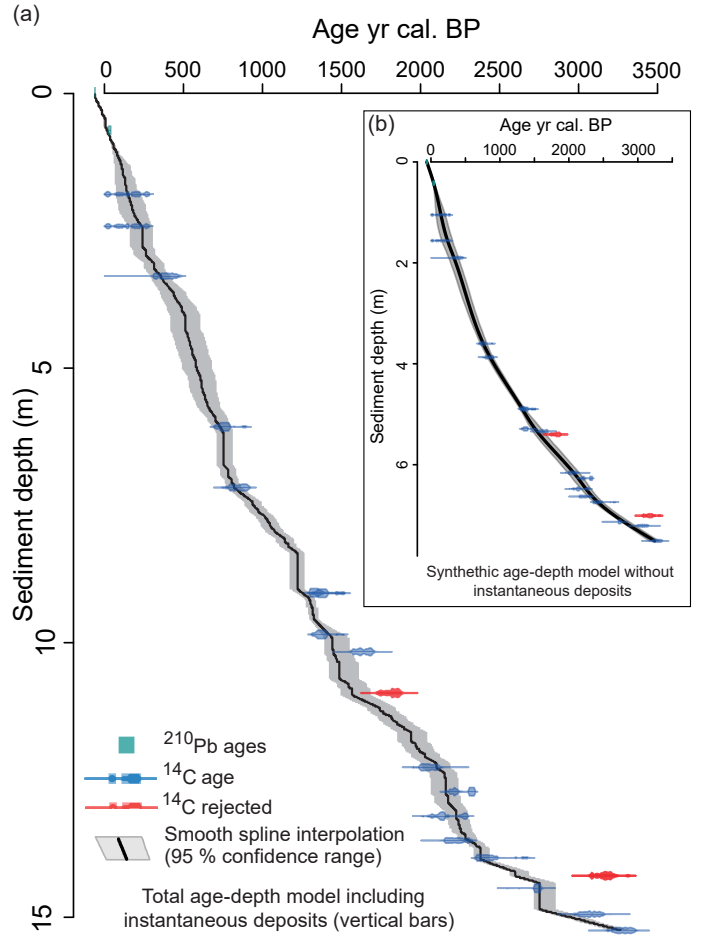

Figure 6. (a) Age-depth model for entire LAU11 sediment sequence including instantaneous deposits based on short-lived radionuclides and radiocarbon derived ages. (b) Synthethic age-depth model free of events for LAU11.

lowing Arnaud et al. (2002). We obtained a mean accumulation rate of $3.7 \pm 0.3 \mathrm{~mm} \mathrm{yr}^{-1}$ with age uncertainties derived from the standard error from the linear regression of the CFCS model (Goldberg, 1963). These low values of ${ }^{210} \mathrm{~Pb}_{\mathrm{ex}}$ were attributed to flood deposits from the nearby Vénéon Valley historical flood record from the RTM-ONF database (http://rtm-onf.ifn.fr/, last access: 26 February 2017). In addition, a total of 19 radiocarbon analyses were performed on plant macroremains, twigs, leaves, tree bark and roots collected in the $15.44 \mathrm{~m}$ sediment sequence (Table 1). Among the results from the 19 samples, two dates were excluded from the age-depth model because they were considered too old, probably due to reworked material from the watershed. To develop a well-constrained chronology, we removed the 153 graded beds that were thicker than $5 \mathrm{~mm}$ and interpreted them as flood-induced deposits (Fouinat et al., 2017a) representing a total of $668.5 \mathrm{~cm}$. The three mass-wasting deposits exhibiting numerous pebble-sized elements, representing a total of $154 \mathrm{~cm}$, were also excluded from the age-depth relationship. The remaining $7.21 \mathrm{~m}$ (Fig. 6) were used to reconstruct a synthetic sedimentary record (Bøe et al., 2006; Giguet-Covex et al., 2012; Wilhelm et al., 2012a). The agedepth relationship was then calculated using a smooth spline interpolation generated using $\mathrm{R}$ software and the R-code package "Clam" version 2.2 (Blaauw, 2010).

\section{Discussion}

\subsection{Event layers}

\subsubsection{Flood-induced deposits}

Normally graded beds identified by F2 plus F3 are common features in lake sediments where they are generally attributed to turbidity currents related to mass movements or flood deposits (Sturm and Matter, 1978; Arnaud et al., 2002; Gilli et al., 2013). In the Q90-Q50 diagram (Fig. 2c), the linear fit suggests an increase of coarser sediment transported and deposited with higher values of median, which was attributed to a sedimentary process regulated by water currents (Passega, 1964; Wilhelm et al., 2012b, 2015). The presence of terrestrial macroremains also suggests turbidity currents originating from the lake catchment. Within some of the turbidites, the presence of pebbles was identified. The pebbles' position within this deposit is quite random because they could be found in the coarse base as well as in the silty clay top of deposits. This feature does not suggest transport of gravels with water current, especially as the main inlet is located at the southern part of the lake more than $300 \mathrm{~m}$ from the coring site. However, a heavy rainfall triggering a flood would probably induce runoff in the steep slopes and avalanche corridors next to the coring site. The gravels within turbidites would likely be originating from slope processes above the coring site, supported by the angular shape and the size of $>2 \mathrm{~mm}$ diameter related to short-distance sediment transport. Moreover, the presence of coarse material identified by CT imagery can also be explained by in-core movement during coring.

\subsubsection{Wet-avalanche-induced deposits}

We observed remarkable deposition of isolated (F1A) as well as aggregated pebbles (F1G) within the fine sediment matrix. Based on the Q90-Q50 diagram (Fig. 2c) similar median values are characterizing F1A and F1G facies, suggesting similar deposition energy. However, both Q90 and sorting values are higher for F1G which is related to an additional sandy fraction in the fine sediment, inducing multimodal grain size distribution (Fouinat et al., 2017a). As observed on pebbles present in the flood-induced deposits, both the angular shape and the large size suggest short-distance transport. Moreover, based on the grain size measurements, we did not identify evidence of gradation or erosive base characterizing debris flow in lacustrine environment, thus excluding a dense subaqueous sediment transport (Sletten et al., 2003; Irmler et al., 2006). The coarse material would then be transported from the steep slopes, without water current, and deposited in the lake basin. Observations in the western part of the watershed, of both wet avalanches cones at the bottom of the avalanche corridors, suggest pebbles origin from the steep slopes. Due to their density and high water content, wet avalanches occurring preferably in spring season would 


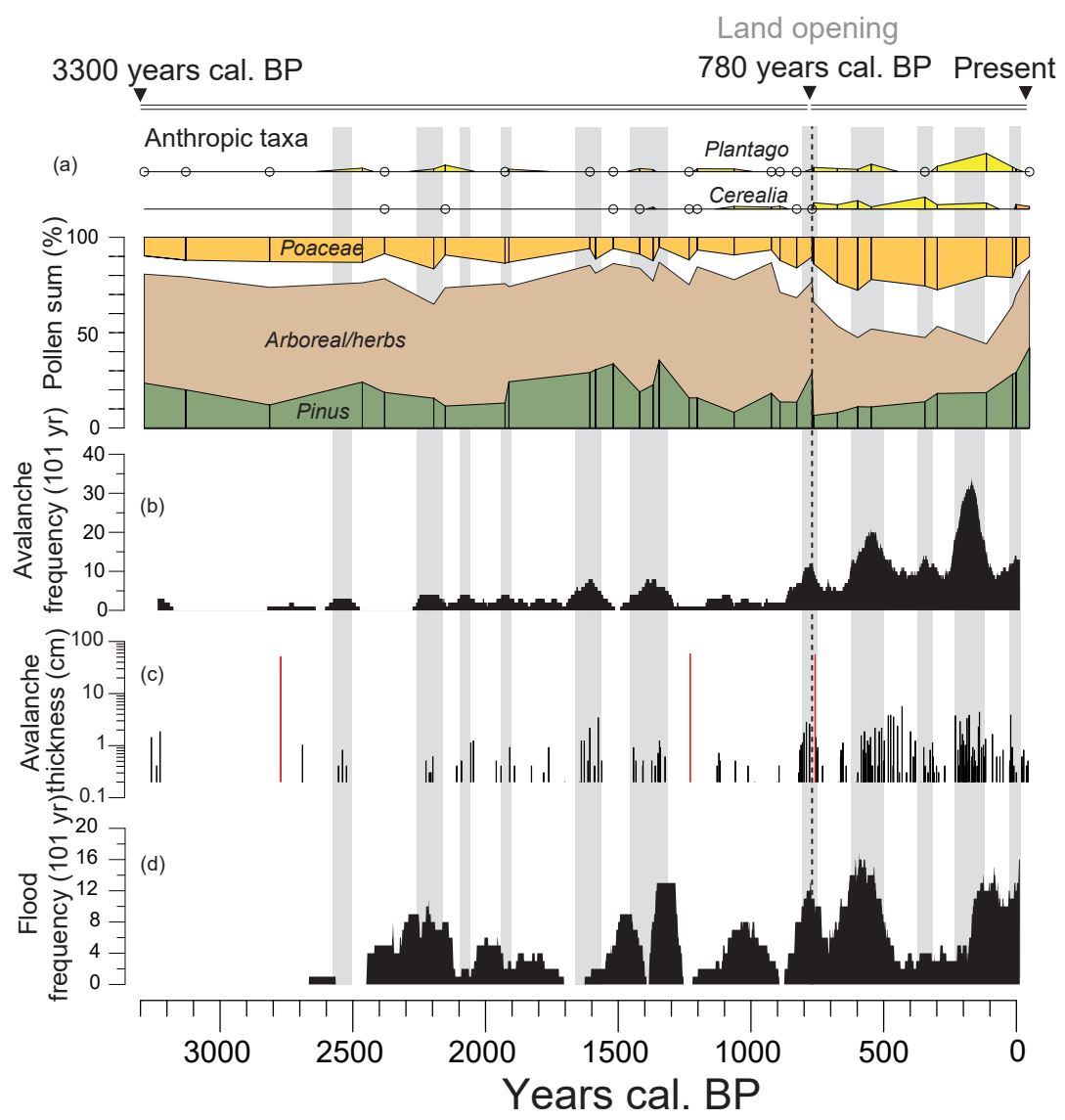

Figure 7. Lake Lauvitel extreme event erosion pattern versus pollen data. (a) Anthropic taxa found in pollen analysis, and pollen sum (\%) of Poaceae, Pinus and ratio between arboreal/herb pollen. (b) Lake Lauvitel avalanche chronicle averaged for 101 years. (c) Lake Lauvitel avalanche thickness in centimeters (red bars correspond to the three thickest avalanche deposits). (d) Lake Lauvitel flood chronicle (101-year average). Grey bands indicate periods of higher avalanche activity.

be either deposited on the lake ice or directly in the water if the ice was already melted. The transported coarse sediment fraction would in the first case be stored on lake ice and then be spread to the lake basin by drifting ice and deposited as drop stones at spring season (Luckman, 1975; Nesje et al., 2007; Vasskog et al., 2011). This scenario would also depend on the quantity of sediment transported and the magnitude of the avalanche flow. From our results it seems difficult to estimate an avalanche magnitude which would probably depend on the quantity of material transported and the distance from the avalanche corridor. In this case, a multicoring study would be more appropriate to precisely characterize the spread of those avalanche deposits. However, a high-magnitude avalanche would probably break the ice and sediment would enter directly into water, creating a large aggregation of sediment at the bottom. This is more likely the case for the three thicker mass-wasting deposits found in LAU11 characterized by heterogeneous fine sediment fractions, numerous pebbles (Fig. 3) and beveled units in the seismic profiles (Fig. 2).

\subsection{Potential influence of vegetation on the avalanche and flood chronicles}

To understand the potential impacts of past human landscape management on the flood and avalanche chronicles, we investigated the past vegetation dynamics. From 3300 to $760 \mathrm{yr}$ cal. BP, pollen analysis exhibits fluctuations of the arboreal taxa from $55 \%$ to $90 \%$ of the total pollen counts, with lower arboreal pollen percentages coinciding with higher percentages of the anthropic taxa (Fig. 7). Those anthropogenic pollens were identified as Plantago and Rumex, suggesting the occurrence of grazing activities, and as Cerealia, suggesting the presence of crops. At approximately $760 \mathrm{yr}$ cal. BP $( \pm 50)$, a major shift in the vegetation cover is interpreted from a drop of the Pinus taxa counts and other trees such as Abies, Pinus and Picea, as well as a sharp increase in Poaceae based on the herb pollen sum nearly reaching $50 \%$ of the total pollen counts. The increase in the herb group coincides with a clear increase in undetermined monolete spores related to ferns present in the undergrowth taxa. However, at the same time, we do not observe any increase 


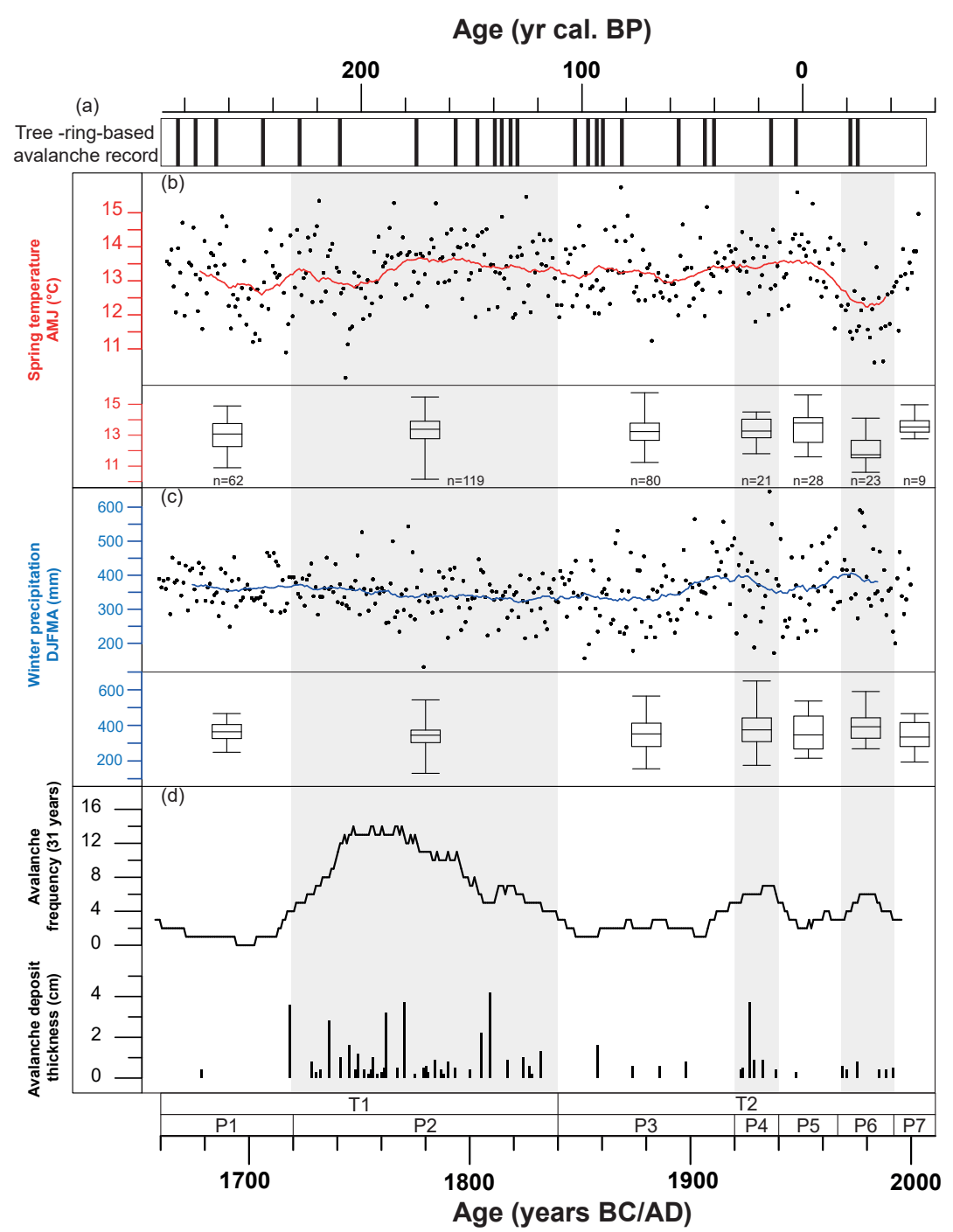

Figure 8. Comparison between Lake Lauvitel avalanche record and climate parameters over the last 350 years. (a) Tree-ring-based avalanche record from Corona et al. (2013); (b) spring temperature (AMJ) record (on a 31-year average in red) and (c) winter precipitation (DJFMA) $(\mathrm{mm})$ (on a 31-year average in blue) based on instrumental and documentary proxy data on a monthly basis from Casty et al. (2005). Data are summarized in box-and-whisker plots corresponding to each identified period (P1 to P7). (d) Lake Lauvitel avalanche frequency and avalanche deposit thickness. Grey bands indicate the period of higher avalanche frequency.

in the Polypodium or Pteridium fern taxa. The presence of the monolete spores could then be related to the reworking of litter material by the erosion of the old spores due to tree clearance (Fig. 5). The pollen record exhibits a progressive increase in the anthropic taxa, leading to a major vegetation change probably related to a strong human pressure. This hypothesis is supported by nearby pollen records exhibiting an increase in the anthropic taxa at comparable dates (Coûteaux, 1983; Tessier et al., 1993; Nakagawa et al., 2000). In the same period, the avalanche record exhibits a considerable increase in frequency (Fig. 7). In addition, we observe the last thick $(52 \mathrm{~cm})$ avalanche event of the entire chronicle, dated at $760 \mathrm{yr}$ cal. BP, denoting poor stabilization of the sediment on the slopes during this period. Based on the pollen analysis and avalanche characteristics, we interpret this event as a result of a major vegetation change related to human practices. Supporting this hypothesis, the average number of avalanches recorded before the deforestation is 2.2 per century, and after $780 \mathrm{yr}$ cal. BP increases to 13.3 per century, increasing the probability to record a wet avalanche by a factor of 6 . We consider this deforestation to be the trigger of a major tipping point in the avalanche regimes. In the case of Lake Lauvitel, the avalanche recurrence strongly increased with the human-induced land cover 


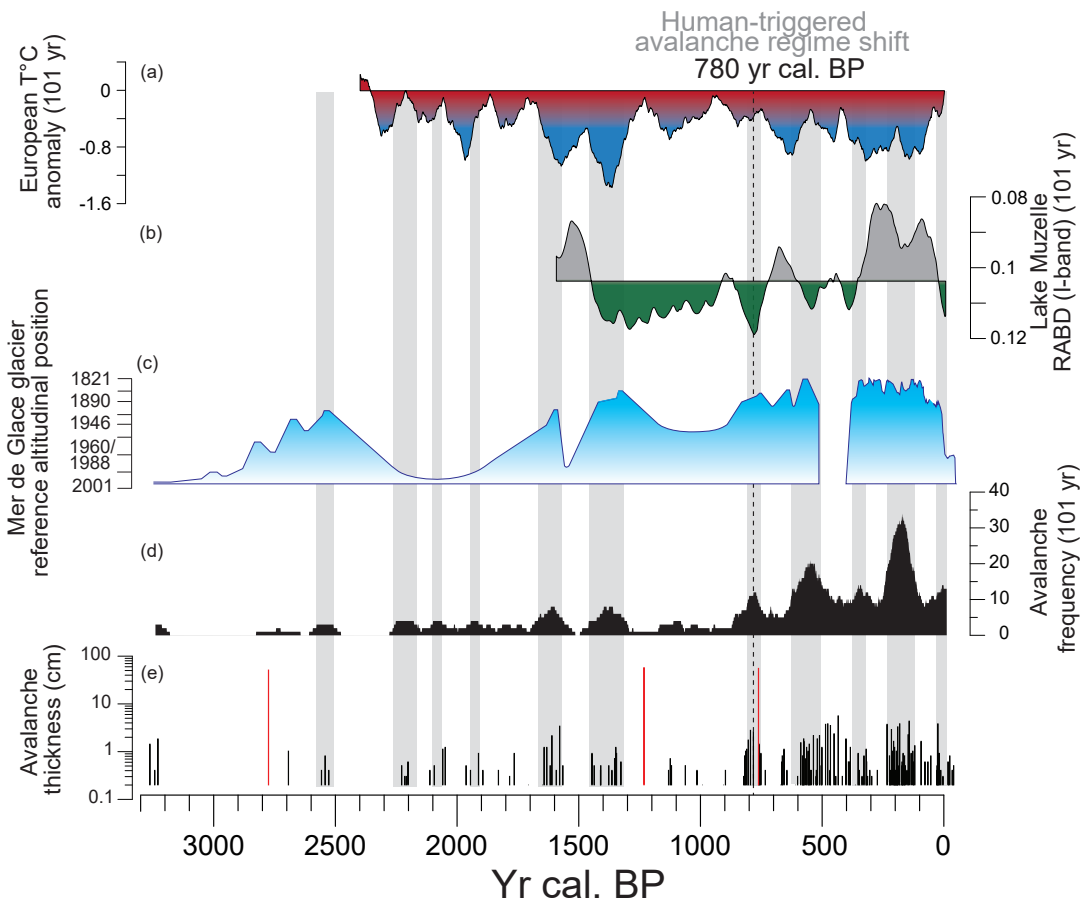

Figure 9. Lake Lauvitel avalanche record compared to climate parameters. (a) European temperature anomaly from Büntgen et al. (2011), (b) nearby Lake Muzelle glacier fluctuation (Fouinat et al., 2017b), (c) the Mer de Glace length record from Le Roy et al. (2015), (d) Lauvitel avalanche frequency on a 101-year average and (e) avalanche thickness $(\mathrm{cm})$.

changes, especially in the western part of the watershed hosting the avalanche corridors. Similar observations led GarcíaHernández et al. (2017) to attribute observed avalanche frequency rise to an increasing in grazing pressure in the Asturian Massif (NW of Spain) at the end of the 19th century. The reconstructed flood frequency increase coincides with the presence of anthropic taxa in the pollen diagram, even before the land opening event. Moreover, higher flood frequency is also observed when Pinus pollen is found in lower proportions in 2380-1930, 1430-1360, 1110-970 and 640$520 \mathrm{yr}$ cal. BP, and additionally after the land opening event in $780 \mathrm{yr}$ cal. BP. Human activities influencing vegetation dynamics in the southern part of the watershed are also supported by the presence of micro-charcoal found in soils. Human activities in those types of Alpine lake settings can have a significant impact on flood activity as previously suggested (Giguet-Covex et al., 2011; Brisset et al., 2017). Erosion process modalities in the southern part of the catchment are still to be studied in order to establish a reliable sediment-based flood chronicle for Lake Lauvitel.

\subsection{Climate forcing on wet avalanches}

\subsubsection{Wet avalanche occurrence compared to climatic instrumental data over the last 350 years}

The presence of pebbles $(>2 \mathrm{~mm})$ in Lake Lauvitel sediment, identified through numerical counting, allows us to reconstruct past avalanche activity (Fouinat et al., 2017a). Wet avalanches are generally interpreted as being triggered by snowpack destabilization mainly due to both thick snow cover and high spring temperature. To assess the local reliability, we compared spring temperature (AMJ) (Fig. 8b) and winter precipitation (DJFMA) (Fig. 8c) from $1660 \mathrm{AD}$ based on instrumental record and documentary proxy data on a monthly basis from Casty et al. (2005). Data are geographically centered on the study site on a $0.5^{\circ} \times 0.5^{\circ}$ spatial grid and averaged over a 31-year period in order to avoid interannual variability.

During the last 350 years, we distinguish between two main intervals, T1 and T2 (1660-1840 and 1840-2000 AD), based on a transition between the minimum arboreal pollen proportions (T1: $45 \%$ ) to a progressive increase to values similar to before the tipping point (T2: $80 \%$ ). Given vegetation has an effect on avalanche occurrence, we need to compare climatic setting within each main interval potentially influencing higher avalanche frequency (grey bands, P2: 1720 1840 AD, P4: 1920-1940 AD, P6: 1969-1992 AD). Within $\mathrm{T} 1,97 \%$ of avalanches occur during the period $\mathrm{P} 2$, which is characterized by warmer median, third quartile and extreme values of spring temperature. Winter precipitation exhibits higher extreme values but the lower median and third quartile are probably denoting a thinner snow cover than P1. According to climate parameters, during low arboreal pollen proportion, avalanches occur preferably during periods of warmer 
spring temperatures but with relatively less winter precipitation. Warmer temperatures enhance snow melting and increase probabilities to have a rain on snow event, favorable to wet avalanche occurrence (Baggi and Schweizer, 2009; Eckert et al., 2013).

In the $\mathrm{T} 2$ interval, higher avalanche frequency periods ( $\mathrm{P} 4$ and P6) exhibit the lowest spring temperatures median and extreme values. In addition, winter precipitation is notably higher (median values, third quartile and extreme values). Thus, avalanches occur preferably during periods of extreme winter precipitation, rather than periods of warmer spring temperature. Based on increased tree cover, more frequent avalanche occurrence could be related to either increased snow loading at lower altitudes or destabilization of the thick snowpack at higher altitudes (e.g., beyond tree line) later in the season.

The longest avalanche record of the French Alps is based on tree rings along the Echalp avalanche path (Fig. 8a), situated approximately $70 \mathrm{~km}$ southeast of Lake Lauvitel in the Queyras massif (Corona et al., 2013). Two periods with high avalanche activity have been identified as $1802-1820$ and 1846-1867 AD. Considering our age model uncertainties for this period ( $\pm 48 \mathrm{yr}$ cal. BP), these two periods could correspond to the two avalanche frequency peaks in Lake Lauvitel (1760-1780 and 1800-1820 AD). Moreover, the period of 1970-1980 AD, known for heavy snowfall in the Alps (Castebrunet et al., 2012), exhibits events in both records. A perfect concordance between those two records is however unlikely as avalanches are controlled by specific extreme weather conditions. Reardon et al. (2008) found that environmental parameters such as vegetation cover are influencing avalanche triggers and that the occurrence of avalanches is associated with positive snowpack anomalies. As snow loading depends on wind direction, discrepancies in snow accumulation are possible from one valley to another (McCollister et al., 2003). In the end, the Lake Lauvitel pebble deposits are in accordance with climate parameters and seem representative of at least the valley sensitivity to avalanches.

\subsubsection{Past wet avalanche activity under regional climatic setting}

To investigate the 3300-year long wet avalanche chronicle (Fig. 9), we compare our avalanche chronicle with records related to winter precipitation and temperature over several millennia. It is commonly accepted that the major factors forcing the Alpine glacial extent are annual temperature and winter precipitation (Vincent, 2005; Solomina et al., 2016). The Mer de Glace glacier length record (Le Roy et al., 2015), located in the western French Alps, as well as the proglacial Lake Muzelle record, located $3 \mathrm{~km}$ from the study site (Fouinat et al., 2017b), allow long-term comparison with past glacier dynamics. Additionally, temperature variability is issued from the central European relative summer temper- ature reconstruction from Büntgen et al. (2011) based on pine and larch tree-rings at high altitude in the Alpine region.

Lake Lauvitel higher wet avalanche frequency occurred in 2570-2510, 2250-2180, 2090-2050, 1945-1910, 16601570, 1460-1320, 860-1730, 640-440, 370-290 and 250$90 \mathrm{yr}$ cal. BP (in grey; Fig. 9d), which coincide with periods of larger extent of the Mer de Glace glacier (Fig. 9c). The only exception is dated at $2250-1910 \mathrm{yr}$ cal. BP, when high frequency is coinciding with a retreated phase of the Mer de Glace but is synchronous with a local glacier advance in the Écrins massif (Le Roy et al., 2017), as well as enhanced glacial activity issued from the Lake Bramant sediment record (Guyard et al., 2007). It is probable, for wet avalanches to occur on a multicentennial timescale, that sufficient winter precipitation is necessary to produce a thick enough snow cover. This result is supported by previous studies on avalanche deposits recorded in lake sediment which attributed increased occurrence to the climate-driven increase in glacial activity (Blikra and Nemec, 1998; Nesje et al., 2007). However, at a sub-centennial scale, Lake Lauvitel avalanche frequency peaks also coincide with both periods of lower clastic input in nearby proglacial Lake Muzelle, denoting a lower influence of glacier erosion in lake sediment (Fig. 9b) and with warmer relative European summer temperatures (Fig. 9a). In this case, temperature control on avalanche occurrence could be significant and would affect the snow cover and create more frequent wet avalanches.

Over long periods, our study highlights both the role of climate parameters (temperature and winter precipitation) and vegetation cover changes on the past wet avalanche hazard. The role of increased winter precipitation related to large glacier advances is essential on snowpack thickness for avalanches to occur. Within these periods, the thick snowpack seems to be preferably destabilized by warmer spring temperatures. In the context of predicted warmer temperatures, wet avalanches could be more frequent, especially in low-forested areas or higher altitudes, either induced by warmer spring temperatures or rain on snow. Further longterm wet avalanches records in the Alpine area would help to better understand special extent of these forcing parameters and verify our interpretations.

\section{Conclusion}

High-resolution sedimentological and CT imagery analyses of Lake Lauvitel sequence revealed 319 event layers over the last 3300 years. A total of 153 of these deposits present a fining upward trend with a strong relationship between median values and coarser percentile suggesting a water current origin. These events were interpreted as flood-related deposits. The other 166 deposits were characterized by a multimodal grain size distribution with presence of a sand fraction but also gravel and pebble size minerogenic elements within a fine sediment matrix with no evidence of grada- 
tion. They were interpreted as induced by wet avalanches. Local human activity was reconstructed using pollen analysis and revealed a major vegetation change at $780 \mathrm{yr}$ cal. BP ( \pm 50 years) interpreted as a large forest clearance. This period may have induced a shift in wet avalanche occurrence and may have caused a tipping point significantly increasing their frequency after this human-induced landscape change.

The comparison between instrumental and climate records on a multicentennial scale shows that wet avalanches in Lake Lauvitel preferably occur during larger glacial extent when climate conditions induce a sufficiently thick snow cover. On a sub-centennial timescale, events are more frequent when spring temperature is warmer, generating snowpack destabilization and/or an increase of rain on snow. Higher winter precipitation has the same effect, even while spring temperatures are relatively colder denoting a probable snowpack destabilization later in the season. Thus, the combination of high winter precipitation and warmer temperatures seems to be major climatic forcing on the occurrence of wet avalanches in Lake Lauvitel both under low and high anthropic pressure on the watershed. In the Alps, predicted warmer temperatures may induce an evolution of the avalanche hazard towards more wet avalanches especially at higher altitudes. Further studies on wet avalanches are necessary in order to better understand past occurrence and climate forcing of these events on a regional scale.

Data availability. The original pebble count, age model and avalanche chronicle produced in this study are available from the Pangaea repository at https://doi.org/10.1594/PANGAEA.892911 (Fouinat et al., 2018).

Sample availability. The sediment core is referenced in IGSN: IEFRA007I; the code can be found in the open international database (www.geosamples.org).

Author contributions. LF, PS, JP and FA elaborated on the manuscript with contributions from all co-authors. FD was in charge of the pollen record. XM made the CT-scan measurements, EC performed the seismic campaign, and PS was the leader of the project.

Competing interests. The authors declare that they have no conflict of interest.

Acknowledgements. Laurent Fouinat's $\mathrm{PhD}$ fellowship was supported by a grant from Écrins National Park, Communauté des Communes de l'Oisans, Deux Alpes Loisirs and the Association Nationale de la Recherche et de la Technologie (ANRT). The coring campaign was funded by a grant of the Pôle Grenoblois Risques Naturels, and cores were retrieved thanks to CLIMCOR Equipex directed and organized by CNRS-INSU. It is supported by the French program "Investissements d'Avenir" through the French funding agency (ANR-11-EQPX-0009-CLIMCOR). The authors would like to thank the Écrins National Park (PNE) for the coring authorization and assistance in the field. ${ }^{14} \mathrm{C}$ analyses were acquired thanks to the CNRS-INSU ARTEMIS national radiocarbon AMS measurement program at Laboratoire de Mesure ${ }^{14} \mathrm{C}$ (LMC14) at the French Alternative Energies and Atomic Energy Commission (CEA) Institute at Saclay and the Poznań Radiocarbon Laboratory. The authors wish to thank the Hôpitaux Univeritaire de Genève (HUG) for the CT-scan measurements.

Edited by: Denis-Didier Rousseau

Reviewed by: two anonymous referees

\section{References}

Ancey, C. and Bain, V.: Dynamics of glide avalanches and snow gliding: Glide avlanches and snow gliding, Rev. Geophys., 53, 745-784, https://doi.org/10.1002/2015RG000491, 2015.

Arnaud, F., Lignier, V., Revel, M., Desmet, M., Beck, C., Pourchet, M., Charlet, F., Trentesaux, A., and Tribovillard, N.: Flood and earthquake disturbance of $210 \mathrm{~Pb}$ geochronology (Lake Anterne, NW Alps), Terra Nova, 14, 225-232, 2002.

Baggi, S. and Schweizer, J.: Characteristics of wet-snow avalanche activity: 20 years of observations from a high alpine valley (Dischma, Switzerland), Nat. Hazards, 50, 97-108, 2009.

Billeaud, I., Chaumillon, E., and Weber, O.: Evidence of a major environmental change recorded in a macrotidal bay (MarennesOléron Bay, France) by correlation between VHR seismic profiles and cores, Geo-Mar. Lett., 25, 1-10, 2005.

Blaauw, M.: Methods and code for "classical" age-modelling of radiocarbon sequences, Quat. Geochronol., 5, 512-518, https://doi.org/10.1016/j.quageo.2010.01.002, 2010.

Blikra, L. H. and Nemec, W.: Postglacial colluvium in western Norway: depositional processes, facies and palaeoclimatic record, Sedimentology, 45, 909-959, https://doi.org/10.1046/j.13653091.1998.00200.x, 1998.

Bøe, A.-G., Dahl, S. O., Lie, Ø., and Nesje, A.: Holocene river floods in the upper Glomma catchment, southern Norway: a high-resolution multiproxy record from lacustrine sediments, Holocene, 16, 445-455, 2006.

Bolte, S. and Cordelieres, F. P.: A guided tour into subcellular colocalization analysis in light microscopy, J. Microsc.-Oxford, 224, 213-232, 2006.

Brisset, E., Guiter, F., Miramont, C., Troussier, T., Sabatier, P., Poher, Y., Cartier, R., Arnaud, F., Malet, E., and Anthony, E. J.: The overlooked human influence in historic and prehistoric floods in the European Alps, Geology, 45, 347-350, https://doi.org/10.1130/G38498.1, 2017.

Büntgen, U., Tegel, W., Nicolussi, K., McCormick, M., Frank, D., Trouet, V., Kaplan, J. O., Herzig, F., Heussner, K.-U., Wanner, H., Luterbacher, J., and Esper, J.: 2500 Years of European Climate Variability and Human Susceptibility, Science, 331, 578582, https://doi.org/10.1126/science.1197175, 2011.

Castebrunet, H., Eckert, N., and Giraud, G.: Snow and weather climatic control on snow avalanche occurrence fluctuations over $50 \mathrm{yr}$ in the French Alps, Clim. Past, 8, 855-875, https://doi.org/10.5194/cp-8-855-2012, 2012. 
Castebrunet, H., Eckert, N., Giraud, G., Durand, Y., and Morin, S.: Projected changes of snow conditions and avalanche activity in a warming climate: the French Alps over the 20202050 and 2070-2100 periods, The Cryosphere, 8, 1673-1697, https://doi.org/10.5194/tc-8-1673-2014, 2014.

Casty, C., Wanner, H., Luterbacher, J., Esper, J., and Böhm, R.: Temperature and precipitation variability in the European Alps since 1500, Int. J. Climatol., 25, 1855-1880, https://doi.org/10.1002/joc.1216, 2005.

Corona, C., Georges, R., Jérôme, L. S., Markus, S., and Pascal, P.: Spatio-temporal reconstruction of snow avalanche activity using tree rings: Pierres Jean Jeanne avalanche talus, Massif de l'Oisans, France, CATENA, 83, 107-118, https://doi.org/10.1016/j.catena.2010.08.004, 2010.

Corona, C., Saez, J. L., Stoffel, M., Rovera, G., Edouard, J.-L., and Berger, F.: Seven centuries of avalanche activity at Echalp (Queyras massif, southern French Alps) as inferred from tree rings, Holocene, 23, 292-304, https://doi.org/10.1177/0959683612460784, 2013.

Coûteaux, M.: Fluctuations glaciaires de la fin du Würm dans les Alpes françaises, établies par des analyses polliniques, Boreas, 12, 35-56, 1983.

Delunel, R., Hantz, D., Braucher, R., Bourlès, D. L., Schoeneich, P., and Deparis, J.: Surface exposure dating and geophysical prospecting of the Holocene Lauvitel rock slide (French Alps), Landslides, 7, 393-400, https://doi.org/10.1007/s10346010-0221-0, 2010.

Eckert, N., Keylock, C. J., Castebrunet, H., Lavigne, A., and Naaim, M.: Temporal trends in avalanche activity in the French Alps and subregions: from occurrences and runout altitudes to unsteady return periods, J. Glaciol., 59, 93-114, https://doi.org/10.3189/2013JoG12J091, 2013.

Faegri, K., Kaland, P. E., and Krzywinski, K.: Textbook of pollen analysis, John Wiley \& Sons Ltd., 1989.

Fierz, C., Armstrong, R. L., Durand, Y., Etchevers, P., Greene, E., McClung, D. M., Nishimura, K., Satyawali, P. K., and Sokratov, S. A.: The international classification for seasonal snow on the ground, UNESCO/IHP, Paris, 2009.

Fouinat, L., Sabatier, P., Poulenard, J., Reyss, J.-L., Montet, X., and Arnaud, F.: A new CT scan methodology to characterize a small aggregation gravel clast contained in a soft sediment matrix, Earth Surf. Dynam., 5, 199-209, https://doi.org/10.5194/esurf5-199-2017, 2017a.

Fouinat, L., Sabatier, P., Poulenard, J., Etienne, D., Crouzet, C., Develle, A.-L., Doyen, E., Malet, E., Reyss, J.-L., Sagot, C., Bonet, R., and Arnaud, F.: One thousand seven hundred years of interaction between glacial activity and flood frequency in proglacial Lake Muzelle (western French Alps), Quaternary Res., 87, 407422, https://doi.org/10.1017/qua.2017.18, 2017b.

Fouinat, L., Sabatier, P., David, F., Montet, X., Schoeneich, P., Chaumillon, E., Poulenard, J., and Arnaud, F.: Extended age model, avalanche chronicle and pebble count of Lake Lauvitel sediment, https://doi.org/10.1594/PANGAEA.892911, 2018.

García-Hernández, C., Ruiz-Fernández, J., Sánchez-Posada, C., Pereira, S., Oliva, M., and Vieira, G.: Reforestation and land use change as drivers for a decrease of avalanche damage in midlatitude mountains (NW Spain), Global Planet. Change, 153, 3550, https://doi.org/10.1016/j.gloplacha.2017.05.001, 2017.
Giguet-Covex, C., Arnaud, F., Poulenard, J., Disnar, J.-R., Delhon, C., Francus, P., David, F., Enters, D., Rey, P.-J., and Delannoy, J.-J.: Changes in erosion patterns during the Holocene in a currently treeless subalpine catchment inferred from lake sediment geochemistry (Lake Anterne, $2063 \mathrm{~m}$ a.s.1., NW French Alps): The role of climate and human activities, Holocene, 21, 651-665, https://doi.org/10.1177/0959683610391320, 2011.

Giguet-Covex, C., Arnaud, F., Enters, D., Poulenard, J., Millet, L., Francus, P., David, F., Rey, P.-J., Wilhelm, B., and Delannoy, J.J.: Frequency and intensity of high-altitude floods over the last $3.5 \mathrm{ka}$ in northwestern French Alps (Lake Anterne), Quaternary Res., 77, 12-22, https://doi.org/10.1016/j.yqres.2011.11.003, 2012.

Gilli, A., Anselmetti, F. S., Glur, L., and Wirth, S. B.: Lake sediments as archives of recurrence rates and intensities of past flood events, in Dating torrential processes on fans and cones, Springer, 225-242, 2013.

Goeury, C.: Acquisition, gestion et représentation des données de l'analyse pollinique sur micro-ordinateur, Travaux de la section scientifique et technique, Institut français de Pondichéry, 25, 405-416, 1988.

Goldberg, E. D.: Geochronology with ${ }^{210} \mathrm{~Pb}$, Radioactive Dating, International Atomic Energy Agency, Vienna, 121-131, 1963

Guyard, H., Chapron, E., St-Onge, G., Anselmetti, F. S., Arnaud, F., Magand, O., Francus, P., and Mélières, M.-A.: High-altitude varve records of abrupt environmental changes and mining activity over the last 4000 years in the Western French Alps (Lake Bramant, Grandes Rousses Massif), Quaternary Sci. Rev., 26, 2644-2660, https://doi.org/10.1016/j.quascirev.2007.07.007, 2007.

Irmler, R., Daut, G., and Mäusbacher, R.: A debris flow calendar derived from sediments of lake Lago di Braies (N. Italy), Geomorphology, 77, 69-78, https://doi.org/10.1016/j.geomorph.2006.01.013, 2006.

Iverson, R. M.: The physics of debris flows, Rev. Geophys., 35, 245-296, 1997.

Lazar, B. and Williams, M.: Climate change in western ski areas: Potential changes in the timing of wet avalanches and snow quality for the Aspen ski area in the years 2030 and 2100, Cold Reg. Sci. Technol., 51, 219-228, 2008.

Le Roy, M., Nicolussi, K., Deline, P., Astrade, L., Edouard, J.-L., Miramont, C., and Arnaud, F.: Calendar-dated glacier variations in the western European Alps during the Neoglacial: the Mer de Glace record, Mont Blanc massif, Quaternary Sci. Rev., 108, 122, https://doi.org/10.1016/j.quascirev.2014.10.033, 2015.

Le Roy, M., Deline, P., Carcaillet, J., Schimmelpfennig, I., and Ermini, M.: 10Be exposure dating of the timing of Neoglacial glacier advances in the Ecrins-Pelvoux massif, southern French Alps, Quaternary Sci. Rev., 178, 118-138, https://doi.org/10.1016/j.quascirev.2017.10.010, 2017.

Luckman, B.: Drop stones resulting from snow-avalanche deposition on lake ice, J. Glaciol, 14, 186-188, 1975.

Luckman, B.: The geomorphic activity of snow avalanches, Geogr. Ann. A., 59, 31-48, 1977.

Martin, J.-P. and Germain, D.: Can we discriminate snow avalanches from other disturbances using the spatial patterns of tree-ring response? Case studies from the Presidential Range, White Mountains, New Hamp- 
shire, United States, Dendrochronologia, 37, 17-32, https://doi.org/10.1016/j.dendro.2015.12.004, 2016.

McCollister, C., Birkeland, K., Hansen, K., Aspinall, R., and Comey, R.: Exploring multi-scale spatial patterns in historical avalanche data, Jackson Hole Mountain Resort, Wyoming, Cold Reg. Sci. Technol., 37, 299-313, 2003.

Moore, J. R., Egloff, J., Nagelisen, J., Hunziker, M., Aerne, U., and Christen, M.: Sediment Transport and Bedrock Erosion by Wet Snow Avalanches in the Guggigraben, Matter Valley, Switzerland, Arct., Antarct., Alp. Res., 45, 350-362, https://doi.org/10.1657/1938-4246-45.3.350, 2013.

Mulder, T., Migeon, S., Savoye, B., and Faugères, J.-C.: Inversely graded turbidite sequences in the deep Mediterranean: a record of deposits from flood-generated turbidity currents?, Geo-Mar. Lett., 21, 86-93, https://doi.org/10.1007/s003670100071, 2001.

Nakagawa, T., Edouard, J.-L., and de Beaulieu, J.-L.: A scanning electron microscopy (SEM) study of sediments from Lake Cristol, southern French Alps, with special reference to the identification of Pinus cembra and other Alpine Pinus species based on SEM pollen morphology, Rev. Palaeobot. Palyno., 108, 1-15, https://doi.org/10.1016/S0034-6667(99)00030-5, 2000.

Nesje, A., Bakke, J., Dahl, S. O., Lie, O., and Boe, A.-G.: A continuous, high-resolution 8500-yr snow-avalanche record from western Norway, Holocene, 17, 269-277, https://doi.org/10.1177/0959683607075855, 2007.

Passega, R.: Grain size representation by CM patterns as a geological tool, J. Sediment. Res., 34, 830-847, 1964

Reardon, B., Pederson, G., Caruso, C., and Fagre, D.: Spatial reconstructions and comparisons of historic snow avalanche frequency and extent using tree rings in Glacier National Park, Montana, USA, Arct. Antarct. Alp. Res., 40, 148-160, 2008.

Reimer, P. J., Bard, E., Bayliss, A., Beck, J. W., Blackwell, P. G., Ramsey, C. B., Buck, C. E., Cheng, H., Edwards, R. L., and Friedrich, M.: IntCal13 and Marine13 radiocarbon age calibration curves 0-50,000 years cal BP, Radiocarbon, 55, 1869-1887, 2013.

Schindelin, J., Arganda-Carreras, I., Frise, E., Kaynig, V., Longair, M., Pietzsch, T., Preibisch, S., Rueden, C., Saalfeld, S., and Schmid, B.: Fiji: an open-source platform for biological-image analysis, Nat. Methods, 9, 676-682, 2012.

Simpkin, P. and Davis, A.: For seismic profiling in very shallow water, a novel receiver, Sea Technol., 34, 21-28, 1993.

Sletten, K., Blikra, L. H., Ballantyne, C., Nesje, A., and Dahl, S. O.: Holocene debris flows recognized in a lacustrine sedimentary succession: sedimentology, chronostratigraphy and cause of triggering, Holocene, 13, 907-920, 2003.

Solomina, O. N., Bradley, R. S., Jomelli, V., Geirsdottir, A., Kaufman, D. S., Koch, J., McKay, N. P., Masiokas, M., Miller, G., Nesje, A., Nicolussi, K., Owen, L. A., Putnam, A. E., Wanner, H., Wiles, G., and Yang, B.: Glacier fluctuations during the past 2000 years, Quaternary Sci. Rev., 149, 61-90, https://doi.org/10.1016/j.quascirev.2016.04.008, 2016.
Stoffel, M. and Bollschweiler, M.: Tree-ring analysis in natural hazards research - an overview, Nat. Hazards Earth Syst. Sci., 8, 187-202, https://doi.org/10.5194/nhess-8-187-2008, 2008.

Sturm, M. and Matter, A.: Turbidites and Varves in Lake Brienz (Switzerland): Deposition of Clastic Detritus by Density Currents, in Modern and Ancient Lake Sediments, Blackwell Publishing Ltd., 147-168, https://doi.org/10.1002/9781444303698.ch8, 1978.

Tessier, L., Beaulieu, J.-L. D., Couteaux, M., Edouard, J.-L., Ponel, P., Rolando, C., Thinon, M., Thomas, A., and Tobolski, K.: Holocene palaeoenvironments at the timberline in the French Alps - a multidisciplinary approach, Boreas, 22, 244 254, https://doi.org/10.1111/j.1502-3885.1993.tb00184.x, 1993.

Touflan, P., Talon, B., and Walsh, K.: Soil charcoal analysis: a reliable tool for spatially precise studies of past forest dynamics: a case study in the French southern Alps, Holocene, 20, 45-52, https://doi.org/10.1177/0959683609348900, 2010.

Valt, M. and Paola, C.: Climate change in Italian Alps: Analysis of snow precipitation, snow durations and avalanche activity, International Snow Science Workshop, 1247-1250, 2013.

Vasskog, K., Nesje, A., Storen, E. N., Waldmann, N., Chapron, E., and Ariztegui, D.: A Holocene record of snow-avalanche and flood activity reconstructed from a lacustrine sedimentary sequence in Oldevatnet, western Norway, Holocene, 21, 597-614, https://doi.org/10.1177/0959683610391316, 2011.

Vincent, C.: Solving the paradox of the end of the Little Ice Age in the Alps, Geophys. Res. Lett., 32, 9706, https://doi.org/10.1029/2005GL022552, 2005.

Wilhelm, B., Arnaud, F., Enters, D., Allignol, F., Legaz, A., Magand, O., Revillon, S., Giguet-Covex, C., and Malet, E.: Does global warming favour the occurrence of extreme floods in European Alps? First evidences from a NW Alps proglacial lake sediment record, Climatic Change, 113, 563-581, https://doi.org/10.1007/s10584-011-0376-2, 2012a.

Wilhelm, B., Arnaud, F., Sabatier, P., Crouzet, C., Brisset, E., Chaumillon, E., Disnar, J.-R., Guiter, F., Malet, E., Reyss, J.-L., Tachikawa, K., Bard, E., and Delannoy, J.-J.: 1400years of extreme precipitation patterns over the Mediterranean French Alps and possible forcing mechanisms, Quaternary Res., 78, 1-12, https://doi.org/10.1016/j.yqres.2012.03.003, 2012b.

Wilhelm, B., Sabatier, P., and Arnaud, F.: Is a regional flood signal reproducible from lake sediments?, Sedimentology, 62, 11031117, https://doi.org/10.1111/sed.12180, 2015. 